\title{
Regulasi Emosi Sebagai Prediktor Perilaku Agresivitas Remaja Warga Binaan LPKA
}

\author{
Syafruddin Faisal Thohar ${ }^{1 *}$ \\ 1. Program Studi Psikologi Islam, STAIN Kediri, Jawa Timur, Indonesia \\ *E-mail: syaft.99@gmail.com
}

\begin{abstract}
Abstrak
Kekerasan fisik dan verbal yang sering terjadi antar warga binaan LPKA adalah bentuk agresivitas yang paling sering terjadi. Secara hipotesis, perilaku agresivitas tersebut disebabkan karena warga binaan yang mayoritas berusia 12 tahun sampai dengan 18 tahun kurang bisa mengendalikan emosinya. Metode penelitian yang digunakan adalah metode kuantitatif dengan tujuan untuk mengetahui pengaruh regulasi emosi terhadap agresivitas. Penelitian ini melibatkan 115 orang narapidana yang ada di Lembaga Pembinaan Khusus Anak (LPKA) Kelas I Kota Blitar. Pengambilan data dalam penelitian menggunakan instrumen Difficulties in Emotion Regulation Scale (DERS-16) untuk mengukur kesulitan dalam meregulasi emosi dan Agression scale untuk mengukur perilaku agresivitas. Hasil penelitian menunjukkan bahwa regulasi emosi berpengaruh secara signifikan terhadap agresivitas (sig. $0,000<0,05)$. Pengaruh regulasi emosi terhadap agresivitas adalah $15,4 \%$.
\end{abstract}

\section{Keywords: Agresivitas; Regulasi Emosi; Remaja}

\section{Mukadimah}

Agresivitas pada remaja sering kali terjadi akibat dari penyelesaian konflik yang kurang tepat (Aryanto, 1992). Beberapa data statistik menunjukkan bahwa agresivitas banyak sekali terjadi. Brazilian National Council for Child and Adolescent Rights menemukan sekitar 6,5 juta anak dan remaja atau sekitar $67 \%$ mengalami kekerasan verbal setiap tahunnya dan kekerasan dalam bentuk fisik terdapat sekitar 18 juta atau $85 \%$ setiap tahun (Algeri \& Souza, 2006). Sedangkan studi di Amerika menunjukkan bahwa 25\% remaja lebih suka menggunakan kekuatan dan agresivitas untuk menyelesaikan konflik mereka (Winter, Neal \& Waner, 2005).

Agresivitas dapat muncul dalam bentuk fisik yang cenderung bersifat langsung maupun verbal yang cenderung bersifat tidak langsung (Parrot \& Giancola, 2007) dan keduanya direspon sama dalam struktur otak seseorang (Eisenberg, Lieberman, \& Williams, 2003), bahkan bentuk verbal bisa lebih menyakitkan daripada fisik (Chen, Williams, Fitness, \& Newton, 2008). Agresivitas dapat menjadi masalah dalam berbagai macam seting kehidupan, termasuk sekolah, tempat kerja, rehabilitasi dan juga lembaga pemasayarakatan (LAPAS) atau Lembaga Pebinaan Khusus Anak (LPKA). Agresivitas dalam lapas sendiri bisa dijelaskan melalui teori "The Importation Model". Penjelasan teori tersebut berfokus pada karakteristik kepribadian yang dibawa oleh narapidana ke dalam penjara. Misalnya narapidana dengan nilai-nilai, sikap, pengalaman, dan norma-norma sosial yang cenderung ke arah perilaku agresif terhadap orang lain akan cenderung melakukan tindakan agresif terhadap narapidana lain. Seringkali narapidana remaja yang berperilaku agresif karena mereka merasa sulit untuk menyesuaikan diri dengan kehidupan penjara, dan karena itu pula mereka terlibat lebih banyak konflik dengan orang lain, dan kemudian mereka melihat agresi sebagai cara yang tepat untuk menangani konflik (Irwin \& Cressey, 1962).

Teori kedua tentang agresivitas dalam LAPAS adalah deprivation model. Teori ini menyebutkan bahwa situasi dimana narapidana berada adalah penyebab dari perilaku agresif. Narapidana dalam 
penjara dibatasi hak-haknya, seperti kebebasan, kenyamanan rumah, dan hubungan sosial, dan pembatasan hak-hak inilah akhirnya menyebabkan frustrasi yang akan menyebabkan perilaku agresif terhadap narapidana lain, bangunan LAPAS, dan staf LAPAS (Harer \& Steffensmeier, 1996).

Beberapa penelitian mencoba untuk menguji tentang teori tersebut salah satunya adalah McCorkle. Dalam penelitian dengan sampel sejumlah 371 narapidana, ditemukan bukti bahwa LAPAS dengan penghuni yang melebihi kapasitas bisa menyebabkan perilaku agresif. Mereka juga menemukan bahwa stress dan merasa kesepian adalah hal yang umum dialami dalam penjara (McCorkle, Miethe \& Drass, 1995). Kontribusi terbesar munculnya agresivitas dalam penjara adalah dikarenakan kelebihan kapasitas (Gaes \& McGuire, 1985; Paulus, cox, McGain, \& Chandler, 1975; Cox, Paulus, \& McGain, 1984). Narapidana dalam penjara yang kelebihan kapasitas harus berbagi fasilitas dengan narapidana lain sehingga dapat memunculkan konflik yang menyebabkan agresivitas (Blackburn, Fowler, \& Pollock, 2012).

LPKA Kelas I Blitar sebagai lembaga pembinaan narapidana anak mampu menampung hingga 270 orang narapidana dan pada saat ini hanya menampung 120 narapidana. Secara teori frekuensi agresivitas dalam penjara adalah sedikit apabila penjara tersebut tidak mengalami kelebihan kapasitas. Namun yang terjadi dilapangan berbeda, masih banyak ditemui kasus agresivitas seperti bullying, saling menghina dan bahkan pemukulan.

Buss dan Perry (1992), mengemukakan beberapa bentuk agresivitas yang bisa muncul dan dialami oleh seseorang. Bentuk-bentuk agresivitas tersebut adalah agresi fisik, verbal, kemarahan (anger) dan kecurigaan (hostility). Agresi fisik dan verbal dapat dikontrol dengan kemampuan mengontrol perilaku melalui kontrol diri dan regulasi emosi, sehingga individu dapat mengontrol emosi dan perilakunya. Kemarahan dapat dikontrol dengan kemampuan mengantisipasi keadaan dengan pertimbangan secara objektif dan kecurigaan (hostility) dapat dikontrol dengan menafsirkan keadaan atau peristiwa, sehingga memperoleh pemahaman terhadap keadaan dan peristiwa secara obyektif.
Penelitian yang dilakukan oleh Roberton, Daffern, \& Bucks (2012) menyatakan bahwa regulasi emosi mampu mengurangi agresivitas. Dijelaskan bahwa agresivitas yang terjadi pada remaja disebabkan karena kurangnya remaja dalam ketrampilan untuk melakukan regulasi emosi.

Regulasi emosi didefinisikan sebagai upaya untuk mempertahankan, menghambat dan meningkatkan pengalaman serta ekspresi emosional individu (Bridges, Denham, \& Ganiban, 2004; Calkins, 2011; Gross, 2002; Rottenberg \& Gross, 2007). Metode regulasi emosi pada individu dilakukan secara otomatis ataupun terkontrol. Regulasi emosi yang dilakukan secara otomatis muncul tanpa kehadiran kesadaran dan juga perhatian. Sedangkan regulasi emosi yang terkontrol muncul dengan tujuan yang jelas, melibatkan usaha sadar dan membutuhkan sumber daya perhatian (Mauss, Bunge, \& Gross, 2007).

Regulasi emosi yang efektif membutuhkan kesadaran, pemahaman dan kejelasan respon emosional. Kemampuan untuk mengenali dan menggambarkan emosi internal pada individu dianggap penting karena menyediakan akses informasi yang terdapat dalam emosi (Gohm \& Clore , 2002; Greenberg, 2007). Kesadaran tentang emosi yang dirasakan itulah yang akan meningkat dan dengan kesadaran emosi yang baik maka individu dapat meregulasi emosi dengan efektif sehingga dapat mereduksi agresivitas.

Berdasarkan uraian di atas, maka dilakukan penelitian tentang pengaruh regulasi emosi terhadap agresivitas. Adapun tujuan penelitian adalah untuk mengetahui adanya pengaruh regulasi emosi terhadap agresivitas.

\section{Metode}

Penelitian ini adalah penelitian korelasional yang menggunakan pendekatan kuantitatif, dimana datanya diolah dan dianalisis menggunakan statistik dan menghasilkan prediksi bahwa suatu variabel mempengaruhi variabel lainnya. Variabel bebas yaitu regulasi emosi, variabel terikatnya yaitu agresivitas.

Subjek penelitian ini adalah seluruh narapidana di Lembaga Pembinaan Khusus Anak (LPKA) Blitar 
yang berjumlah 115 orang berusia 13 sampai 18 tahun dengan Mean $=16,556$ dan $\mathrm{SD}=1,371$. Mayoritas subjek berusia 16 sampai 17 tahun sebesar 65\%. Berdasarkan tingkat pendidikan subjek penelitian, mayoritas pendidikan subjek adalah SD sejumlah 53 orang dengan prosentase sebesar $46 \%$, subjek dengan pendidikan setingkat SMP berjumlah 49 dengan prosentase $42 \%$, subjek dengan tingkat pendidikan setingkat SMA adalah yang paling sedikit, yaitu 13 orang dengan prosentase sebesar $12 \%$. Berikut adalah sajian data penyebaran responden berdasarkan jenis kelamin, usia dan tingkat pendidikan.

Tebel 1.

Deskripsi Karakteristik Responden $(\mathbf{n}=115)$.

\begin{tabular}{lcccc}
$\begin{array}{c}\text { Karakterist } \\
\text { ik }\end{array}$ & $\begin{array}{c}\text { Frekuen } \\
\text { si }\end{array}$ & $\begin{array}{c}\text { Persenta } \\
\text { se }\end{array}$ & $\begin{array}{c}\text { Mea } \\
\text { n }\end{array}$ & Sd \\
\hline Usia & & & & \\
\hline$<15$ tahun & 32 & $28 \%$ & 14,81 & 0,47 \\
& & & 2 & 0 \\
\hline 16-17 tahun & 65 & $56 \%$ & 16,81 & 0,39 \\
& & & 5 & 1 \\
\hline$>$ 18 tahun & 18 & $16 \%$ & 18,72 & 0,82 \\
& & & 2 & 6 \\
\hline
\end{tabular}

\begin{tabular}{ccccc}
\hline Pendidikan & & & & \\
\hline Sd & 53 & $46 \%$ & - & - \\
\hline Smp & 49 & $42 \%$ & - & - \\
\hline Sma & 13 & $12 \%$ & - & - \\
\hline Total & 115 & $100 \%$ & - & - \\
\hline
\end{tabular}

Instrumen yang digunakan dalam penelitian ini adalah skala agresivitas yang digunakan merupakan self-report yang diguakan untuk mengukur agresivitas pada remaja yang disebut Aggression Scale (AS) disusun oleh Orpinas dan Frankowski (2001). Aggresssion scale yang digunakan terdiri dari 11 item dalam skala Likert berbentuk pernyataan yang berisi tentang berapa kali subjek melakukan agresivitas dalam tujuh hari terakhir. Aspek-aspek yang diukur adalah agresivitas verbal, agresivitas non-verbal, dan kemarahan. Agression scale memiliki 7 pilihan jawaban, yaitu angka 0 kali melakukan perilaku dalam pernyataan, 1 kali, 2 kali, 3 kali, 4 kali, 5 kali, dan 6 kali lebih. Semakin tinggi skor yang didapatkan maka semakin tinggi agresivitas yang ada pada subjek dan skor rendah mengindikasikan subjek sedikit melakukan agresivitas. Cara mengerjakannya adalah dengan cara melingkari pilihan jawaban yang sesuai dengan subjek, respon mulai dari 0 kali hingga 6 kali lebih. Contoh item: "Saya menggganggu teman saya agar mereka marah". Aggression Scale memiliki konsistensi internal sebesar $\alpha=0,82$.

Instrumen untuk regulasi emosi yang digunakan adalah Difficulties in Emotion Regulation Scale-16 (DERS-16) yang disusun oleh Gratz dan Roemer (2004). Instrumen ini digunakan untuk mengukur tingkat kesulitan dalam meregulasi emosi pada anak, remaja dan dewasa. DERS-16 terdiri dari 16 item yang dibagi kedalam 6 aspek. a) Aspek yang berkaitan dengan tidak mampu memahami respon dari emosi, b) Aspek yang berhubungan dengan kesulitan dalam menentukan tujuan, c) aspek yang berkaitan dengan kesulitan dalam mengontrol impuls, d) Aspek yang berkaitan dengan kurangnya kesadaran terhadap emosi, e) Aspek yang berkaitan dengan keterbatasan dalam strategi regulasi emosi, dan f) Aspek yang berkaitan dengan kurang dalam memahami emosi. Cara mengerjakan skala ini dengan memilih respon antara 0 hingga 4 sesuai dengan pernyataan yang diberikan. Contoh item: "Ketika sedih, saya sulit untuk berpikir tentang hal lain", kemudian subjek memilih respon dengan menuliskan angka sesuai dengan yang dialami subjek. DERS-16 berbentuk skala likert yang semua itemnya adalah unfavorable dengan pilihan respon mulai dari $4=$ tidak pernah, $3=$ kadang-kadang, $2=$ hampir setengah waktu, $1=$ sering dan $0=$ selalu. Skor DERS-16 yang tinggi mengindikasikan bahwa subjek memiliki regulasi emosi yang baik, sedangkan skor rendah mengindikasikan bahwa subjek memiliki regulasi emosi yang buruk.

Analisis data dalam penelitian ini menggunakan analisis regresi dengan model regresi linear yang mana dalam persamaan regresinya mengandung unsur interaksi dari dua variabel (Ghozali, 2006) dengan bantuan SPSS v.22 for windows. Analisis ini digunakan untuk mengetahui pengaruh variabel independent (regulasi emosi) terhadap variabel dependent (agresivitas). Dari hasil analisis data tersebut akan diketahui pengaruh variabel bebas terhadap variabel terikat serta dapat mengetahui besarnya pengaruh variabel prediktor.

\section{Hasil}

Variabel yang diteliti adalah regulasi emosi, dan agresivitas. Data variabel regulasi emosi 
menunjukkan bahwa rata-rata tingkat regulasi emosi pada subjek penelitian adalah sedang, ditunjukkan oleh nilai mean sebesar 45,486. Begitu pula dengan variabel agresivitas. Subjek penelitian memiliki tingkat agresivitas yang sedang ditunjukkan oleh nilai mean sebesar 12,330. Secara ringkas rentang skor, mean dan standar deviasi dapat dilihat pada Tabel 2.

Tabel 2.

Deskripsi Variabel Penelitian $(\mathbf{n}=115)$

\begin{tabular}{cc} 
Variabel & $\begin{array}{c}\text { Rentang } \\
\text { Skor }\end{array}$ \\
\hline
\end{tabular}

$\begin{array}{lll}\text { Regulasi } & 20-61 & 45,486 \\ \text { Emosi } & & \end{array}$

Agresivitas $\quad 0-38 \quad 12,330 \quad 9,139$

Keterangan : SD $=$ Standar Deviasi

Hasil uji korelasi menunjukkan hubungan yang negatif dan signifikan $(r=-0,394, p=0,000)$ antara variabel regulasi emosi dengan variabel agresivitas. Sehingga semakin individu memiliki regulasi emosi yang tinggi maka semakin rendah perilaku agresivitasnya dan begitu pula sebaliknya.

Tabel 3.

Uji Korelasi Antar Varabel

\begin{tabular}{lcc}
\hline \multicolumn{1}{c}{ Variabel } & $\begin{array}{c}\text { Regulasi } \\
\text { emosi (X2) }\end{array}$ & $\begin{array}{c}\text { Agresivitas } \\
(\mathbf{Y})\end{array}$ \\
\hline Regulasi emosi (X2) & 1 & $-0.394^{* * *}$ \\
\hline Agresivitas (Y) & - & 1
\end{tabular}

Keterangan: *** $\mathrm{p}<0.001$

Penentuan jenis analisis data dilakukan dengan uji asumsi klasik yang bertujuan untuk menguji bagus atau tidaknya model regresi yang terbentuk. Pengujian yang dilakukan meliputi uji normalitas, uji heterokedastisitas, dan uji multikolinearitas. Hasil uji asumsi yang pertama adalah uji normalitas memakai Kolmogrov-Sminorv menunjukkan bahwa data yang digunakan dalam penelitian berdistribusi normal $(Z=0,79, p=0,77)$. Selanjutnya adalah uji homogenitas yang dilakukan untuk mengetahui bahwa populasi dalam penelitian memiliki varian yang sama. Hasil dari uji homogenitas menunjukkan bahwa variabel regulasi emosi memiliki varian yang sama dengan variabel agresivitas $(\mathrm{F}=20,775, \mathrm{p}=0,283)$.

Hasil uji linearitas menunjukkan adanya hubungan linear yang signifikan antara variabel bebas dengan variabel terikat. Sedangkan dari uji multikolinearitas menunjukkan bahwa tidak terjadi multikolinearitas antar variabel penelitian $(\mathrm{VIF}=$ $1,306, p=0,000)$. Uji terakhir yang dilakukan adalah uji heterokedastisitas untuk menguji apakah

SDdalam model regresi terjadi ketidaksamaan varian dari residual satu variabel ke variabel lain. Model 28,994gresi yang baik adalah yang tidak terjadi heterokedastisitas. Hasil dari uji heterokedastisitas

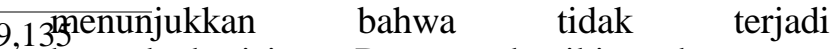
heterokedastisitas. Dengan demikian data yang didapatkan telah memenuhi syarat untuk dianalisis menggunakan model regresi.

Analisis pengaruh antar variabel dilakukan menggunakan analisis regresi linear yang bertujuan untuk mengetahui besarnya pengaruh variabel bebas terhadap variabel terikat. Berdasarkan hasil analisis regresi diambil kesimpulan bahwa regulasi emosi dalam penelitian ini berpengaruh secara signifikan terhadap agresivitas $(\beta=0,301, \mathrm{p}=$ $0,000)$. Pengaruh regulasi emosi adalah sebesar $15,4 \%$. Sehingga dapat disimpulkan bahwa regulasi emosi bisa menjadi variabel prediktor pengaruh terhadap agresivitas.

Tabel 4.

Hasil Uji Regresi Antar Variabel

\begin{tabular}{lcc}
\multicolumn{1}{c}{ Variabel } & $\begin{array}{c}\text { Koefisien } \\
\text { Beta }\end{array}$ & $\mathbf{R}^{\mathbf{2}}$ \\
\hline $\begin{array}{l}\text { Regulasi emosi }- \\
\text { Agresivitas }\end{array}$ & $0,301 * * *$ & 0,154 \\
\hline
\end{tabular}

Keterangan: $* * * \mathrm{p}<0.001$

\section{Diskusi}

Hasil penelitian yang dilakukan menunjukkan bahwa pengaruh regulasi emosi terhadap agresivitas adalah sebesar 15,4\% sesuai dengan penelitian yang 
dilakukan oleh Roberton, Daffern, dan Bucks (2012). Penelitian ini juga mendukung teori Hurlock (1993) yang berpendapat bahwa remaja cenderung memiliki emosi yang bergejolak sehingga kurang mampu meregulasi emosi. Di usia remaja, kemampuan untuk mengelola emosi belum berkembang secara matang. Adanya kemampuan regulasi emosi yang baik dapat membantu seseorang dalam mengontrol dirinya untuk tidak terlibat dalam perilaku yang negatif terutama ketika sedang mengalami masalah dan tekanan. Ini berarti, kemampuan dalam meregulasi emosi mempengaruhi kemampuan seseorang dalam mengontrol perilakunya sehingga dengan adanya kemampuan regulasi emosi yang baik dapat membuat seseorang mengarahkan perilakunya menjadi lebih bertanggung jawab.

Pengekspresian emosi, baik negatif ataupun positif, merupakan hal yang sehat dan konstruktif asalkan dilakukan dengan tepat dan apabila dilakukan kurang tepat maka akan muncul perilaku yang negatif pula. Reivich dan Shatte (2002) mengemukakan dua hal penting yang terkait dengan regulasi emosi, yaitu ketenangan (calming) dan fokus (focusing). Individu yang mampu mengelola kedua keterampilan ini, dapat membantu meredakan emosi yang ada, memfokuskan pikiran-pikiran yang mengganggu dan mengurangi stres.

Kostiuk \& Gregory, (2002) menggambarkan regulasi emosi sebagai kemampuan merespon proses - proses ekstrinsik dan intrinsik untuk memonitor, mengevaluasi, dan memodifikasi reaksi emosi yang intensif dan menetap untuk mencapai suatu tujuan. Ini berarti apabila individu mampu mengelola emosi - emosinya secara efektif, maka individu tersebut akan memiliki daya tahan yang baik dalam menghadapi masalah dan mampu berperilaku positif.

Adapun ciri-ciri individu yang dapat melakukan regulasi emosi dengan baik ialah memiliki kendali diri, hubungan interpersonal yang baik, sikap hatihati, mudah beradaptasi, toleransi terhadap frustasi, pandangan yang positif, peka terhadap perasaan orang lain, melakukan introspeksi dan relaksasi, lebih sering merasakan emosi positif daripada emosi negatif serta tidak mudah putus asa.
Aspek penting dalam regulasi emosi ialah kapasitas untuk memulihkan kembali keseimbangan emosi meskipun pada awalnya seseorang kehilangan kontrol atas emosi yang dirasakannya. Selain itu, seseorang hanya dalam waktu singkat merasakan emosi yang berlebihan dan dengan cepat menetralkan kembali pikiran, tingkah laku, respon fisiologis dan dapat menghindari efek negatif akibat emosi yang berlebihan (Gratz \& Roemer, 2004).

\section{Kesimpulan}

Berdasarkan hasil analisis yang dilakukan, dapat disimpulkan bahwa regulasi emosi berpengaruh terhadap agresivitas. Pengaruh tersebut adalh sebesar $15,4 \%$, sedangakan $84,6 \%$ sisanya dipengaruhi oleh factor-faktor lain.

Hubungan antar variabel menunjukkan adanya korelasi negative dan signifikan antara regulasi emosi dengan agresivitas. Artinya apabila tingkat regulasi emosi individu tinggi maka agresivitasnya menurun begitu pula sebaliknya apabila individu kesulitan dalam meregulasi emosi maka tingkat agresivitasnya akan semakin tinggi.

\section{Saran}

Diharapkan bagi peneliti berikutnya untuk mengembangkan penilitian ini dengan metode eksperimen sehingga lebih mampu menjelaskan pengaruh regulasi emosi terhadap agresivitas. Selain itu juga diharapkan mengembangkan penelitian dengan variabel lainnya dengan mempertimbangkan faktor-faktor yang mempengaruhi timbulnya agresivitas pada remaja selain regulasi emosi.

Untuk lembaga pembinaan diharapkan menyediakan fasilitas untuk melatih remaja warga binaan dalam mengontrol emosi sehingga mampu mengurangi agresivitas yang terjadi di dalam LPKA.

\section{Referensi}

Algeri, S., \& Souza, L. M. D. (2006). Violence against children and adolescents: a challenge in the daily work of the nursing team. Revista Latino-Americana de Enfermagem, 14(4), 625-631.

Aryanto, A. (1992). Tinjauan teori Reasoned Action dan Planned Behaviour mengenai tingkah laku terlibat 
dalam perkelahian pada siswa SLTA dan STM di Jakarta. Master's Thesis, Fakultas Psikologi, Universitas Indonesia Jakarta.

Baron, R.A. \& Byrne, D.E. (2004). Social psychology. Boston: Pearson/Allyn and Bacon.

Blackburn A, Pollock J \& Fowler S. (2012). Prisons: Today and Tomorrow. Burlington: Jones \& Bartlett Learning.

Bridges, L. J., Denham, S. A., \& Ganiban, J. M. (2004). Definitional issues in emotion regulation research. Journal of Child Development, 75(2), 340-345.

Brigham,J.C. (1991). Social psychology. New York: Harper collins publisher Inc.

Buss, A. H., \& Perry, M. (1992). The aggression questionnaire. Journal of Personality and Social Psychology, 63(3), 452.

Calkins, S. D. (2011). Sustained attention development during the toddlerhood to preschool period: Associations with toddlers' emotion regulation strategies and maternal behaviour. Infant and Child Development, 20(6), 389-408.

Chen, Z., Williams, K. D., Fitness, J., \& Newton, N. C. (2008). When hurt won't heal: Exploring the capacity to relive social and physical pain. Psychological Science, 19(8), 789-795.

Cox, V. C., Paulus, P. B., \& McCain, G. (1984). Prison crowding research: The relevance for prison housing standards and a general approach regarding crowding phenomena. American Psychologist, 39, $1148-1160$

Eisenberg, N., Fabes, R. A., Guthrie, I. K., \& Reiser, M. (2000). Dispositional emotionality and regulation: their role in predicting quality of social functioning. Journal of Personality and Social Psychology, 78(1), 136.

Eisenberger, N., Lieberman, M. D. \& Williams, K. D. (2003). Does rejection hurt? An FMRI study of social exclusion. Science, 302(5643), 290-292.

Gaes, G.G. \& MCGuire, W.F. (1985). Prison Violence: The contribution of crowding versus other determinants of prison assault rates. Journal of Research in crime and Delinquency, vol. 22(1), 41-65.

Ghozali, I. (2006). Analisis multivariate lanjutan dengan SPSS. Semarang: Badan Penerbit Universitas Diponegoro..

Gohm, C. L., \& Clore, G. L. (2002). Four latent traits of emotional experience and their involvement in wellbeing, coping, and attributional style. Cognition and Emotion, 16(4), 495-518.

Gratz, K. L. \& Roemer, L. (2004). Multidimensional assessment of emotion regulation and dysregulation: Development, factor structure, and initial validation of the Difficulties in Emotion Regulation Scale. Journal of Psychopathology and Behavioral Assessment, 26(1), 41-54.

Greenberg, L. S. (2007). Emotion coming of age. Clinical Psychology: Science and Practice, 14(4), 414-421.

Gross, J. J. (2002). Emotion regulation: Affective, cognitive, and social consequences. Psychophysiology, 39(03), 281-291.
(2007). Handbook of Emotion Regulation. New York: Guilford Press.

Gross, J. J., \& Thompson, R. A. (2007). Emotion regulation: Conceptual Foundations. In James J. Gross (ed.), Handbook of Emotion Regulation. (2007). Guilford Press 3-24.

Harer, M., \& Steffensmeier, J. (1996). Race and prison violence. Criminology, 34(3), 323-357.

Hurlock, E.B. (1993). Psikologi Perkembangan: Suatu Pendekatan Sepanjang Rentang Kehidupan. Jakarta: Erlangga.

Irwin, J., \& Cressey, D. (1962). Thieves, convicts and the inmate culture. Social Problems, 10, 145-155.

Kostiuk, L. M., \& Gregory G. T. (2002). Understanding of emotions and emotion regulation in adolescent females with conduct problems: A qualitative analysis. The Qualitative Report, 7(1), 1-15.

Mauss, I. B., Bunge, S. A., \& Gross, J. J. (2007). Automatic emotion regulation. Social and Personality Psychology Compass, 1(1), 146-167.

McCorkle, R. C., Miethe, T. D., \& Drass, K. A. (1995). The roots of prison violence: A test of the deprivation, management, and not-so-total institution models. Crime and Delinquency, 41(3), 317-332.

Nashori, F. (2008). Psikologi sosial islami. Jakarta: PT refika aditama.

Orpinas, P., \& Frankowski, R. (2001). The aggression scale: A self-report measure of aggressive behavior for young adolescents. Journal of Early Adolescence, 21(1), 50-67.

Parrott, D. J., \& Giancola, P. R. (2007). Addressing - The criterion problem in the assessment of aggressive behavior: Development of a new taxonomic system. Aggression and Violent Behavior, 12(3), 280-299.

Paulus, P., Cox, V., McCain, G., \& Chandler, J. (1975). Some Effects of Crowding in a Prison Environment. Journal of Applied Social Psychology, 5(1), 86-91.

Reivich, K., \& Shatte, A. (2002). The resilience factor. New York: Broadway Books.

Roberton, T., Daffern, M., \& Bucks, R. S. (2012). Emotion regulation and aggression. Aggression and Violent Behavior, 17(1), 72-82.

Rottenberg, J., \& Gross, J. J. (2007). Emotion and emotion regulation: A map for psychotherapy researchers. Clinical Psychology: Science and Practice, 14(4), 323-328.

Winter, J., Neal, J. C., \& Waner, K. K. (2005). Student teams learning to cope with conflict. The Delta Pi Epsilon Journal, 85(2), 67-74. 